\title{
The Novel and Minimally Invasive Treatment Modalities for Female Pelvic Floor Muscle Dysfunction; Beyond the Traditional
}

\author{
Yiğit Akın¹, Matthew Young², Muhammad Elmussareh², Nickolaus Charalampogiannis ${ }^{3}$, Ali Serdar Gözen ${ }^{3}$
}

\author{
${ }^{1}$ Department of Urology, İzmir Katip Çelebi University School of Medicine, İzmir, Turkey \\ ${ }^{2}$ Clinic of Urology, Mid Yorkshire Hospitals NHS Trust, Wakefield, The United Kingdom \\ ${ }^{3}$ Department of Urology, SLK-Kliniken Heilbronn, University of Heidelberg, Heilbronn, Germany
}

Pelvic floor dysfunction is a clinical entity that is prevalent among female patients. Determining the exact underlying cause of pelvic floor dysfunction is difficult, and surgical intervention for this clinical entity may be challenging. Pelvic floor dysfunction can affect the quality of life of the patient by causing stress urinary incontinence, pelvic organ prolapse, or both. Well-defined surgical treatment options, minimally invasive approaches, and novel techniques for the treatment of pelvic floor dysfunction have been recently introduced. Here, we evaluated the management options available for patients with stress urinary incontinence and pelvic organ prolapse. We searched Medline and EMBASE databases for relevant articles by using the keywords "pelvic floor dysfunction," "minimally invasive procedures," "stress urinary incontinence," "pelvic organ prolapse," and "novel techniques". Traditional treatment options for stress urinary incontinence and pelvic organ prolapse are beyond the scope of our review. Laparoscopic and robotic surgical treatments for pelvic floor dysfunction continue to evolve and develop. These minimally invasive techniques will soon replace open procedures. Alternative novel treatment modalities have also been developed from novel human-compatible materials and are emerging as successful treatments for stress urinary incontinence. The development of these various treatment options has implications for future surgical practice in the field of uro-gynecology.

Keywords: Minimally invasive surgery, pelvic floor, pelvic organ prolapse, stress urinary incontinence
The pelvic floor, which comprises pelvic bone, muscles and connective tissue, supports and is vital for the normal functions of the pelvic organs, particularly the urinary bladder, urethra, rectum, and the reproductive system $(1,2)$. Pelvic floor dysfunction (PFD) is a collection of complex clinical findings. The symptoms of PFD include pelvic pain, pressure, dyspareunia, stress urinary incontinence (SUI), incomplete urinary voiding, defecatory dysfunction, and pelvic organ prolapse (POP) (3). PFD is more common among females than among males and is often the result of vaginal childbirth $(4,5)$. The other recognized major risk factors for PFD include age, obesity, menopause, and pregnancy $(5,6)$. PFD affects the quality of life of patients and therefore is of great clinical importance (7). Surgical intervention remains the definitive treatment option for patients with symptomatic POP or SUI. In a large population-based study in the United States, the lifetime risk of any primary surgery for SUI or POP reaches $20 \%$ ages of 80 years women (8). The American Urology Association quotes a high percentage of $30 \%$ in patients undergoing surgery for SUI
(9). Surgical and medical technologies in this field have rapidly advanced over the past two decades (10). Minimally invasive surgical options available to patients have expanded, and alternative and novel approaches, such as biological tissue fibrin materials and injectable biological agents (IBAs), have been developed to improve the management of SUI and POP secondary to PFD. Given the increased prevalence of obesity among the aging general population, PFD will become an ever-increasing presentation to uro-gynecologists and specialists of female urology. Minimally invasive treatments are therefore vital to improve the management of this growing cohort of patients.

Here, we describe the clinical presentation and assessment of patients presenting with SUI and POP and summarize the evidence for various alternative and minimally invasive approaches for PFD treatment. We have avoided focusing on traditional conservative treatments, namely pelvic floor exercises and the widely accepted practice of midurethral tape surgery, because these treatment modalities are well reported in current literature on PFD management.

\footnotetext{
Address for Correspondence: Dr. Ali Serdar Gözen, Department of Urology, SLK-Kliniken Heilbronn, University of Heidelberg, Heilbronn, Germany e-mail: ali.goezen@slk-kliniken.deＯRCID ID: orcid.org/0000-0002-9975-443X

Received: 4 May $2018 \quad$ Accepted: 21 June $2018 \cdot$ DOI: 10.4274/balkanmedj.2018.0869

Available at www.balkanmedicaljournal.org

Cite this article as:

Akın Y, Young M, Elmussareh M, Charalampogiannis N, Gözen AS. The Novel and Minimally Invasive Treatment Modalities for Female Pelvic Floor Muscle Dysfunction; Beyond the Traditional. Balkan Med J 2018;35:358-66

${ }^{\circ}$ Copyright 2018 by Trakya University Faculty of Medicine / The Balkan Medical Journal published by Galenos Publishing House.
} 


\section{STRESS URINARY INCONTINENCE}

SUI is described as "the observation of involuntary leakage from the urethra, synchronous with exertion/effort, or on sneezing or coughing" (11). The prevalence of SUI increases among the female population with age. For example, the prevalence of SUI increases from $16 \%$ among women under 30 years to $29 \%$ among women aged 30-60 years old (12). Well-documented risk factors for the development of SUI include childbirth, childbirth mode, obesity, smoking, and age (13-16). Cesarean sections, a mode of childbirth, exert a protective effect on the pelvic floor reported by Al-Mufti et al. (17). Alternative differential diagnoses must be considered prior to embarking on treatment for SUI. Patients may also experience the symptoms of urge urinary incontinence (UUI) in addition to SUI. The clinician must correctly identify the predominant symptoms to provide the most appropriate treatment to patients with mixed urinary incontinence. UUI is often treated medically upon the first occurrence, whereas SUI often requires additional intervention (18). In addition to providing their clinical history, patients should also complete a bladder diary to assess their fluid intake and voiding habits, as well as the frequency of incontinence episodes. This assessment should be followed by a detailed physical examination, including neurological assessment (19). Pad tests and Q-tip tests can be useful in determining whether the patient will benefit from a urethral sling. Urodynamic studies can help confirm the patients' diagnosis, particularly prior to surgical intervention (20). Conservative options, mainly pelvic floor exercises and weight loss, are usually the first line of treatment for SUI. Other nonsurgical options include electrical and magnetic stimulation, duloxetine use, vaginal inserts (incontinence pessaries and tampons), and topical estrogens (21-23). Despite these treatments, as many as $30 \%$ of patients with SUI undergo surgical interventions (9). Various surgical techniques for SUI exist. These techniques include Burch retropubic colposuspension, tension-free vaginal tapes, transobturator tapes, midurethral slings, and minislings (24). Sling operations often require the use of prolene mesh devices (25). The use of paravaginal grafting techniques has also been reported (26). The increased scrutiny and additional restrictions received by the use of mesh devices (27) in the last decade highlight the need for novel and alternative treatments for the management of POP and SUI.

\section{Stress Urinary Incontinence Treatments}

\section{Radiofrequency Denaturation}

Radiofrequency denaturation is a nonsurgical technique that involves the insertion of a device into the urethra under local anesthesia. Radiofrequency energy is then applied to the bladder neck and proximal urethra to denature and promote the remodeling of collagen in the surrounding tissue (28). Patient outcomes were variable with reported "cure rates" of 22\%-67\% (29). A 3-year prospective study showed significant improvement in the patients' quality of life following treatment with RD but did not compare $\mathrm{RD}$ with other treatments (30).

A Cochrane systematic review concluded that insufficient evidence exists to determine whether RD improves the symptoms of SUI when compared with the sham treatment (31).
No evidence supports that RD is comparable with other established treatments for SUI, such as pelvic floor physiotherapy, pessaries, surgery, or IBAs. The recurrence of lower urinary tract symptoms within 3 years of treatment delivery has been reported, with dysuria being the most common complaint (29). Additional randomized controlled trials are needed to accurately determine the efficacy of $\mathrm{RD}$ in clinical practice.

\section{Injectable Biological Agents}

IBAs have been used for several decades. These materials are applied to increase tissue volume within the proximal urethral wall between the bladder neck and the external urethral sphincter. Increasing tissue volume at these locations increases urethral luminal coaptation and bladder outflow resistance (32). IBAs are delivered endoscopically with a cystoscope via needle injection into the periurethral area. The European Association of Urology guidelines recommend the use of IBAs for the temporary treatment of symptoms in patients who have failed conservative treatments for SUI. It can also be offered an alternative to a midurethral sling (33).

Various bulking agents have been developed and trialed. These IBAs include autologous fat, cross-linked collagen, graphitecoated zirconium beads, polytetrafluroethylene, silicon, dimethylsulfoxide and ethylene vinyl alcohol copolymers, hyaluronic acid, dextranomer microspheres, and calcium hydroxyapatite (34-36). Treatment with IBAs improves SUI symptoms by $18 \%-40 \%$ (28). The efficacy of IBAs is superior to that of pelvic floor physiotherapy but is inferior to that of surgical management (36). Collagen has been removed from the clinical arena but has been used as the standard reference for new agents in clinical trials (35). A Cochrane systematic review found that none of the new agents are inferior to collagen but have failed to reach a consensus on the superior agent or the effect of injection location within the urethra on patient outcomes (35). Novel IBAs (polyacrylamide hydrogel) have decreased patient incontinence episodes by $50 \%$ or greater in $53.2 \%$ of 12 months after treatment (37). IBAs may be cost effective in the initial treatment of patients with SUI without hypermobility or as a surgical adjunct. However, their long-term (greater than 15 months) economic viability is questionable when compared with that of traditional sling surgery for SUI (35). Common complications following the injection of IBAs include urinary retention (up to 30\%) and urinary tract infection (up to $25 \%$ ) (38). Rare complications include abscess formation following collagen injection and fat embolism after autologous fat injection (38).

\section{Stem-cell Injections for Urethral Sphincter Restoration}

This treatment aims to restore the external urethral sphincter through the injection of stem cells (often skeletal muscle-derived or adipose tissue-derived) into and around the sphincter (39). This treatment has been developed in animal models by Xu et al. (40), who successfully demonstrated the restoration of the urethral sphincter in a pudendal nerve-transected rat following the injection of muscle-based stem cells. Recently, a small phase-one clinical trial on the outcomes of the periurethral injection of stem cells has 
been reported. Arjmand et al. (41) reported favorable outcomes for women treated with autologous adipose-derived stem cells injected into the periurethral area for SUI (42). Core blood stem cells have been used by Lee et al. (42) with reasonable success $(n=39)$ in female patients with SUI. Among these patients, 67\% showed improvement at 12 months postinjection. Peters et al. (43) reported favorable outcomes following the injection of increasing doses of autologous muscle-derived stem cells into the urinary sphincter. However, several publications reported minimal improvement in voiding or in the results of urodynamic assessment, as well as the delayed onset of symptom improvement $(44,45)$. This treatment modality remains in its infancy, with evidence to date being collected mainly from animal models and small-scale phase-one clinical trials. Ethical considerations and concerns regarding the regulatory control of stem-cell research have affected the expansion of this field (45).

\section{Fibrin Sealant}

Biocompatible fibrin glue is another endoscopic treatment for SUI that has existed since the 1990s $(46,47)$. It involves the transvaginal placement of fibrin sealant to stimulate a fibrotic reaction, which elevates the vesicle-urethral junction. Data on the long-term outcomes of this treatment option remain lacking, with few published articles since the late 1990s.

\section{Laparoscopic and Robotic-assisted Surgical Modalities}

Open Burch colposuspension was the gold standard surgical technique for the management of SUI until the early 1990s (48). At 1 year postoperation, $85 \%-90 \%$ of patients are continent. This rate drops to $70 \%$ at 5 years postoperation. In 1991, Vancaillie and Schuessler (49) successfully reported the first laparoscopic Burch colposuspension. Following its introduction into clinical practice, laparoscopic treatment for SUI has become increasingly adopted, and evidence showing that its clinical outcomes are equivalent to that of colposuspension with the added benefits of minimally invasive surgery has accumulated. These benefits include reduced blood loss, length of hospital stay, postoperative pain, and catheterization period (50-52). Some authors have argued that laparoscopic colposuspension should be considered as the treatment of choice for women, especially young women, undergoing pelvic floor repair and concomitant retropubic surgery because it avoids the well-documented complications of mesh migration and erosion (53). Laparoscopic techniques for colposuspension using mesh and staples instead than the classical suturing technique have been described. A randomized controlled trial, however, has shown that this technique is associated with unfavorable outcomes (54). The challenging and most timeconsuming aspect of laparoscopic colposuspension is the process of laparoscopic suturing in the pelvis. The development of robotic surgical systems has attempted to overcome this challenge (55). Robotic systems have revolutionized pelvic surgery, particularly uro-pelvic oncology. Three-dimensional-image displays and 720-degree robotic arm articulation have considerably facilitated suture-intensive procedures, such as laparoscopic colposuspension. Successful feasibility studies on the role of robotic-assisted surgery in SUI and voiding dysfunction after urogynaecological surgery have been conducted over the last 3-4 years $(56,57)$. Modified single-series robotic-assisted approaches have been described in the contemporary literature with successful outcomes (58). No study has compared the outcomes of robotic-assisted techniques with either open or laparoscopic colposuspension. If benign urogynecological surgery follows the same trend as other pelvic surgical specialties, then robotic-assisted surgery for SUI is likely to become an increasing popular and cost effective technique in this specialty. SUI treatment modalities based on minimally invasive and laparoscopic and robotic interventions are summarized in Table 1. The published literature on novel techniques for the management of patients with SUI is presented in Table 2.

\section{PELVIC ORGAN PROLAPSE}

POP in females can be defined as the descent and/or herniation of pelvic organs from their normal anatomical location toward or through the vaginal opening. This condition can affect the patient's quality of life and sexual function (59). In females, the utero-sacral ligament, paravaginal attachments, and perineal body constitute the main parts of the system that supports pelvic organs and are interconnected with the endopelvic fascia (60). Any defect in this network may cause POP. Sacral nerve roots S2-4, via the pudendal nerve, are vitally important in the function of the pelvic floor. Defects in neurological communication in these nerves can interfere with the integrity of the pelvic organs and the function of the pelvic floor. Risk factors for the development of POP are similar to those for the development of SUI. Aging, multiparity, and obesity increase the prevalence of POP (61-63). Previous hysterectomy is also a risk factor for POP (63). Chronic constipation and ethnicity (Caucasian, followed by Latin-American, followed by Africa-American women in decreasing order of prevalence) have also been implicated in the development of POP $(64,65)$. Many patients with POP are asymptomatic. However, symptomatic patients can present with a variety of symptoms that may be specifically related to prolapsed structures, such as a bulge or the sensation of pressure within the vagina. Other symptoms include lower urinary tract and defecatory or sexual dysfunction symptoms (63). POP and SUI symptoms considerably overlap (66). As with SUI, the patient's complete medical history must be collected and a thorough physical examination must be performed as part of the initial assessment of POP. POP is classified into four levels in accordance with the descriptions provided by The International

TABLE 1. Stress urinary incontinence treatments based on minimally invasive and laparoscopic and robotic interventions

\begin{tabular}{lc}
\hline Interventions & Success rate \\
\hline Radiofrequency denaturation & $22 \%-67 \%$ \\
Injectable bulking agents & $21 \%-67 \%$ \\
$\begin{array}{l}\text { Stem-cell injections for urethral sphincter } \\
\text { restoration }\end{array}$ & $67 \%$ \\
$\begin{array}{l}\text { Fibrin sealant } \\
\text { Laparoscopic and robotic-assisted surgical } \\
\text { modalities }\end{array}$ & $63 \%$ \\
\hline
\end{tabular}


TABLE 2. Summary of the literature reviewed related to novel techniques for the management of stress urinary incontinence

\begin{tabular}{|c|c|c|}
\hline Author/year & Study design & $\begin{array}{l}\text { Number of patients } \\
\text { (if applicable) and } \\
\text { follow-up }\end{array}$ \\
\hline \multicolumn{3}{|l|}{ Radiofrequency denaturation } \\
\hline Lukban (29) & Literature review & N/A \\
\hline Elser et al. (30) & $\begin{array}{c}\text { Prospective } \\
\text { observational study }\end{array}$ & $\begin{array}{c}n=139 \\
\text { 36-month follow-up }\end{array}$ \\
\hline Kang et al. (31) & Systematic review & $\begin{array}{c}\mathrm{n}=173 \\
\text { included sham-RCT }\end{array}$ \\
\hline \multicolumn{3}{|l|}{ Injectable bulking agents } \\
\hline Davila (28) & Literature review & N/A \\
\hline Haab et al. (34) & $\begin{array}{c}\text { Prospective } \\
\text { observational study }\end{array}$ & $\begin{array}{c}n=67 \\
\text { 7-month follow-up }\end{array}$ \\
\hline Kirchin et al. (35) & Systematic review & $\mathrm{n}=2004$ in 14 trials \\
\hline $\begin{array}{l}\text { Mamut and Carlson } \\
\text { (36) }\end{array}$ & Literature review & N/A \\
\hline Sokol et al. (37) & $\begin{array}{c}\text { Single-blinded } \\
\text { randomized controlled } \\
\text { trial }\end{array}$ & $\begin{array}{c}n=345 \\
\text { 12-month follow-up }\end{array}$ \\
\hline Matsuoka et al. (38) & Systematic review & $\mathrm{n}=942$ from 14 trials \\
\hline
\end{tabular}

Stem-cell injections for urethral sphincter restoration

$\begin{array}{lcc}\text { Arjmand et al. (41) } & \begin{array}{c}\text { Observational } \\ \text { prospective series }\end{array} & \begin{array}{c}\mathrm{n}=10 \\ \text { 24-week follow-up }\end{array} \\ \text { Lee et al. (42) } & \begin{array}{l}\text { Observational } \\ \text { prospective series }\end{array} & \mathrm{n}=39 \\ \text { Peters et al. (43) } & \begin{array}{c}\text { Prospective clinical } \\ \text { trial with varying doses } \\ \text { of stem cells }\end{array} & \mathrm{n}=80 \\ & \text { 12-month follow-up } \\ \begin{array}{l}\text { Kuismanen et al. } \\ \text { (44) }\end{array} & \mathrm{n}=5 \\ \text { Aragón et al. (45) } & \text { Literature review } & \text { 12-month follow-up } \\ \end{array}$

Fibrin sealant

$\begin{array}{ll}\begin{array}{l}\text { Falconer and } \\ \text { Larsson (46) }\end{array} & \text { Case series } \\ \text { Killholma et al. (47) } & \text { Case series }\end{array}$

Case series

Laparoscopic and robotic-assisted surgical modalities

$\begin{array}{cc}\text { Reid and Smith (50) } & \begin{array}{c}\text { Literature review of } \\ \text { two large randomized } \\ \text { controlled trials }\end{array} \\ \text { Hong et al. (51) } & \begin{array}{c}\text { Prospective } \\ \text { observational study }\end{array}\end{array}$

Conclusions

Conclusions

\author{
$\sqrt{3}$
}

ee


TABLE 2. Continued

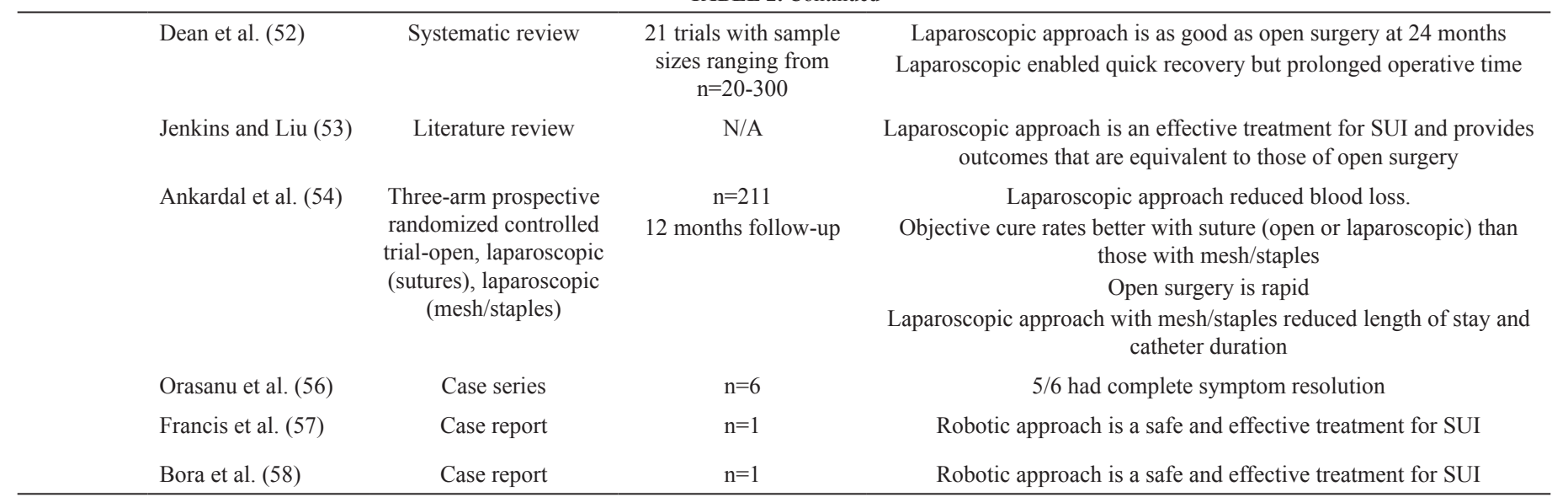

IBA: injectable biological agents; IIQ: incontinence impact questionnaire; N/A: not applicable; RCT: randomized controlled trial; SUI: stress urinary incontinence; QoL: quality of life; UDI: urogenital distress inventory

Continence Society (67):

Level 1: Distal part of POP is up to $1 \mathrm{~cm}$ over the hymen.

Level 2: Distal part of POP is $1 \mathrm{~cm}$ or more over the hymen.

Level 3: Distal part of POP exceeds $1 \mathrm{~cm}$ over the hymen and is less than $2 \mathrm{~cm}$ outside the body.

Level 4: Complete vaginal eversion.

Treatment options can be broadly divided into conservative or surgical options. Conservative measures include smoking cessation and lifestyle modifications (increased exercise, weight loss, and pelvic floor exercises) (68). Vaginal pessaries are widely used to successfully control symptoms with success rates of 50\%$70 \%(69,70)$. Surgical treatments are offered to patients who have declined or failed conservative measures.

Most women with symptomatic POP that continues to persist despite conservative measures are treated through reconstructive procedures. Obliterated procedures are reserved for women who cannot tolerate major surgery or who are not sexually active.

\section{Pelvic Organ Prolapse Treatment Options}

\section{Transvaginal Sacrospinous Ligament Suspension Stapled Fixation}

In this surgical technique, the bilateral sacrospinous ligament is suspended by using surgical staples. It was first described in 1997 by Febbraro et al. (71) in a case series of 34 patients with levels 3 or 4 POP. The sacrospinous ligament suture fixation is a well-documented surgical treatment for POP, with acceptable complication rates and cure rates of $50 \%-100 \%$ (72). The cost of stapling devices is the limiting step in the technique described by Febbraro et al. (71) and when compared with a cheaper and equally effective existing technique, the stapled method is not cost effective.

\section{Anterior Suturing Device}

The use of a suturing device $\left(\mathrm{Capio}^{\circledR}\right)$ for the fixation of the sacrospinous ligament has been recently described. The device is a suture-performing system with a taper-cut needle and attached suture. The needle carrier is enclosed in the concave distal segment of the device's shaft. It is designed to allow the surgeon to drive and retrieve the suture in one step. In a comparative case series, Leone Roberti Maggiore et al. (73) found that traditional sutured fixation using the $\mathrm{Capio}^{\circledR}$ system reduced operative time and reduce blood loss while delivering comparable clinical outcomes at 3-year follow-up (73). Other observational series have also reported favorable outcomes, with reported cure rates of nearly $90 \%$ and only $10.6 \%$ POP recurrence (74).

\section{Laparoscopic Sacrocolpopexy}

Laparoscopic sacrocolpopexy was introduced in 1991 as an adaptation of the well-described open surgical approach. Open sacrocolpopexy was widely regarded as the gold-standard surgical treatment for POP with long-term success rates of 78\%$100 \%$ (75). A randomized controlled trial by Freeman et al. (76) revealed clinical equivalence between open and laparoscopic sacrocolpopexy. Numerous retrospective case series have confirmed that the laparoscopic approach is a safe and effective alternative treatment for the surgical management of POP while conferring the well-documented advantages of minimally invasive surgery. Laparoscopic surgery has been shown to reduce surgical complications $(7.7 \%$ for open and $4 \%$ for laparoscopic repair), pain, UTI rate, and urinary retention (75). Although reoperation rates for POP were higher in the laparoscopic group (5.7\%) than in the open surgery group (3.8\%), this difference was not statistically significant $(\mathrm{p}=0.29)$ (75). Similar findings have been reported by other authors $(77,78)$ with excellent 5 -year anatomical and functional outcomes being reported by Sarlos al. (79). As with any laparoscopic pelvic procedure, the main learning curve for the procedure centers on the mastery of laparoscopic suturing in the tight confines of the pelvis (80). As robotic-assisted surgery gathers momentum to address this challenge, the role of the "traditional" laparoscopic sacrocolpopexy may become limited.

\section{Robotic-assisted Laparoscopic Sacrocolpopexy}

The ever-expanding role of robotic-assisted procedures now 


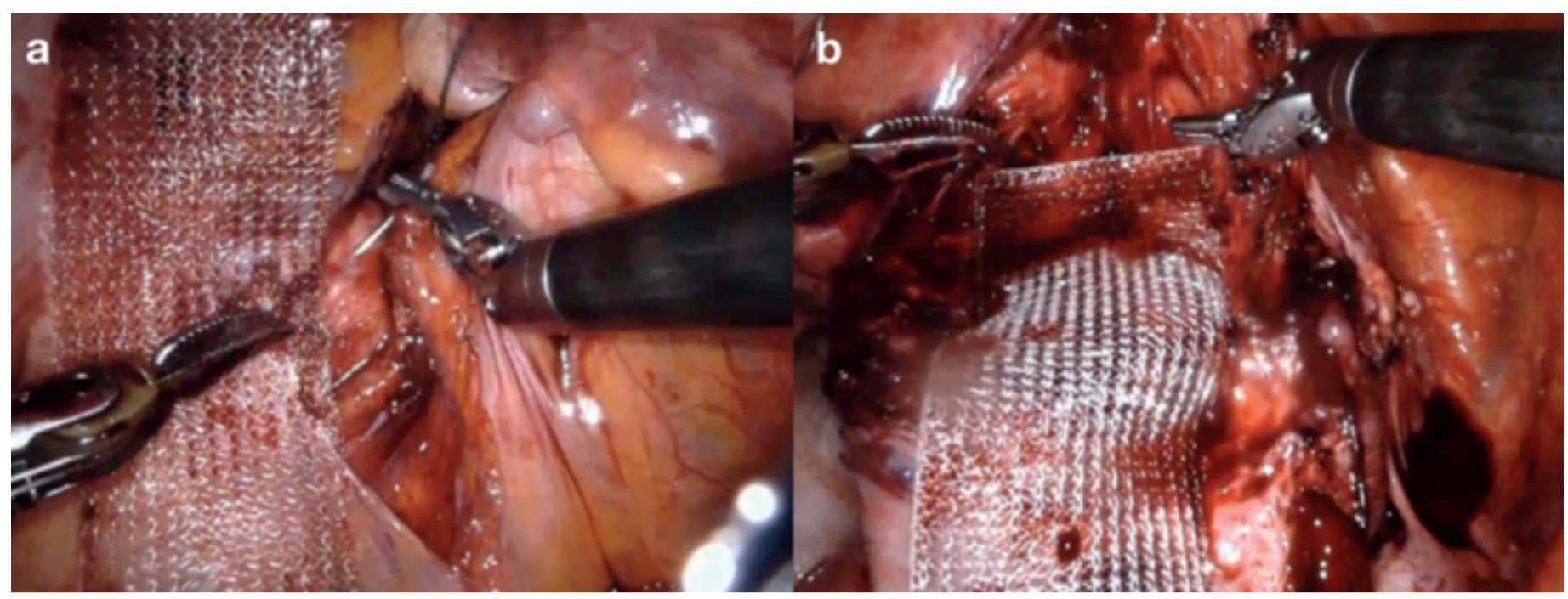

FIG. 1. a,b. Dissection (a) and mesh graft placement (b) during robotic-assisted laparoscopic sacrocolpopexy.

includes sacrocolpopexy. The advantages of robotic-assisted pelvic procedures have been extensively reported in the literature $(67,79)$. Robotic-assisted laparoscopic sacrocolpopexy (RAS) aims to overcome the lengthy learning curve associated with complex laparoscopic surgery. A large systematic review and meta-analysis of the published literature by Serati et al. (80) revealed that RAS is a safe and effective treatment option for patients with POP. When compared with open sacrocolpopexy, RAS increases operative time, but significantly reduces blood loss and length of hospital stay. Objective cure rates for RAS range from $84 \%-100 \%$ with the prolapse recurrence rate of $6.4 \%$ and reoperation rate of $3.3 \%$ (80). Interestingly, several articles have reported an overall cost benefit of RAS over open surgery. Figure 1 shows the dissection of tissues and placement of the mesh graft. Given that the mesh should not touch the bowel and intestine, surrounding tissues should be enclosed (Figure 2). A randomized controlled trial comparing RAS and open sacrocolpopexy showed that RAS does not significantly increase costs when the initial robot purchase and maintenance cost are excluded. Compared with laparoscopic sacrocolpopexy, RAS is associated with decreased blood loss and increased operative times (80). No significant difference exists between the clinical outcomes of RAS and laparoscopic sacrocolpopexy (80). POP treatment modalities based on minimally invasive and laparoscopic and robotic interventions are shown in Table 3. The published literature is summarized in Table 4. An awareness of alterative and novel treatments for PFD is crucial given the current controversy surrounding the use of mesh technology in uro-gynecological practice. Robotic-assisted surgery for SUI and POP is undergoing exponential development. The ability to offer a plethora of minimally invasive and nonsurgical techniques for

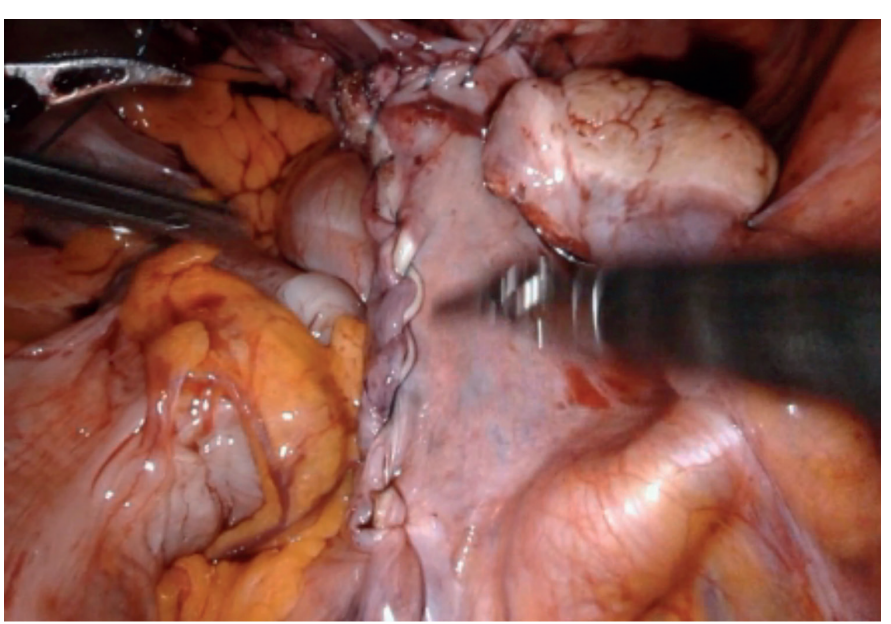

FIG. 2. The mesh is placed under the peritoneum. All tissues are enclosed after roboticassisted laparoscopic sacrocolpopexy.

TABLE 3. Pelvic organ prolapse treatment modalities based on minimally invasive and laparoscopic and robotic interventions

\begin{tabular}{lc}
\hline Interventions & Success rate \\
\hline Transvaginal sacrospinous ligament & $50 \%-100 \%$ \\
suspension stapled fixation & \\
Anterior suturing device & $90 \%$ \\
Laparoscopic sacrocolpopexy & $78 \%-100 \%$ \\
Robotic-assisted laparoscopic sacrocolpopexy & $84 \%-100 \%$ \\
\hline
\end{tabular}

the treatment of PFD has become increasingly necessary as the human population continues to age and individuals present with increasingly multiple medical comorbidities. 
TABLE 4. Summary of the literature reviewed related to novel techniques for the management of patients with pelvic organ prolapse

\begin{tabular}{ccc}
\hline Author/year & Study design & $\begin{array}{c}\text { Number of patients } \\
\text { (if applicable) and } \\
\text { follow-up }\end{array}$ \\
\hline
\end{tabular}

Transvaginal sacrospinous ligament suspension stapled fixation

Febbraro et al. (71) Prospective case series

Tseng et al. (72)

Anterior suturing device

Leone Roberti
Maggiore et al. (73)
Vaudano and Gatti (74)
Comparative case
series

Observational retrospective study

Laparoscopic sacrocolpopexy $\mathrm{n}=165$

Mean follow-up of 43 months

Price et al. (78)

Sarlos et al. (79)
Randomized controlled trial

Prospective observational study

Retrospective observational study

Prospective observational study $\mathrm{n}=84$

$\mathrm{n}=101$

5-year follow-up
Robotic-assisted laparoscopic sacrocolpopexy $\mathrm{n}=1488$ from 27

\section{Mean follow-up of 19 \\ months}

studies

$\mathrm{n}=86$

3-year follow-up

$\mathrm{n}=47$

months

$77 \%$ had a perfect anatomical result

1/37 experienced POP recurrence

This treatment is a safe and well-documented option for POP It can facilitate concurrent pelvic floor repair

No difference in the postoperative complication rates and surgical outcomes of the two modalities

Capio device reduced operating time and blood loss

$89.3 \%$ subjective cure rate

5/47 experienced POP recurrence
Laparoscopic approach increased reoperative rates and increased mesh-related complications if combined with hysterectomy

Open approach increased postoperative cardio-pulmonary complications

Equivalent clinical outcomes between both approaches but laparoscopic surgery reduced length of stay and blood loss

Anatomical success in $94.9 \%$

$5.1 \%$ experienced POP recurrence

$100 \%$ of patients objectively reported "good" vault support on the POP-Q

Subjective cure rate of $95.3 \%$ at 5 years

11 anatomical recurrences

Reoperation rate of $3.5 \%$

\begin{abstract}
$$
\text { Serati et al. (80) }
$$
Systematic review

Serati et al. (80)

N/A: not applicable; POP: pelvic organ prolapse

Editor-in-Chief's note: Ali Serdar Gözen is the member of the Editorial Board of Balkan Medical Journal. However, he did not take place at any stage on the editorial decision of the manuscript.
\end{abstract}

Objective cure rate of $84 \%-100 \%$

Subjective cure rate of $92 \%-95 \%$

Most cost-effective approach was laparoscopic, followed by robotic, then open

Conflict of Interest: No conflict of interest was declared by the authors.

Financial Disclosure: No financial disclosure was declared by the authors.

\section{REFERENCES}

1. Shelton AA, Welton ML. The pelvic floor in health and disease. West J Med 1997; 167:90-8.

2. Cherry DA, Rothenberger DA. Pelvic floor physiology. Surg Clin North Am 1988;68:1217-30.

3. Keane DP, Sims TJ, Abrams P, Bailey AJ. Analysis of collagen status in premenopausal nulliparous women with genuine stress incontinence. Br J Obstet Gynaecol 1997;104: 994-8.
4. Thom D. Variations in estimates of urinary incontinence prevalence in the community: effects of differences in definition, population characteristics, and study type. J Am Geriatr Soc 1998;46:473-80.

5. Lal M, Pattison HM, Allan TF, Callender R. Postcesarean pelvic floor dysfunction contributes to undisclosed psychosocial morbidity. J Reprod Med 2009;54:53-60.

6. Snooks SJ, Swash M, Henry MM, Setchell M. Risk factors in childbirth causing damage to the pelvic floor innervation. Int J Colorectal Dis 1986;1:20-4.

7. Saboia DM, Firmiano MLV, Bezerra KC, Vasconcelos JA Neto, Oriá MOB, Vasconcelos CTM. Impact of urinary incontinence types on women's quality of life. Rev Esc Enferm USP 2017;51:e03266.

8. Wu JM, Matthews CA, Conover MM, Pate V, Jonsson Funk M. Lifetime risk of stress urinary incontinence or pelvic organ prolapse surgery. Obstet Gynecol 2014;123:1201-6.

9. Dmochowski RR, Blaivas JM, Gormley EA, Juma S, Karram MM, Lightner DJ, et al. Update of AUA guideline on the surgical management of female stress urinary incontinence. J Urol 2010;183:1906-14. 
11. Abrams P, Cardozo L, Fall M, Griffiths D, Rosier P, Ulmsten U, et al. The standardization of terminology in lower urinary tract function: report from the standardization sub-committee of the International Continence Society. Urology 2003;61:37-49.

12. Hampel C, Wienhold D, Benken N, Eggersmann C, Thüroff JW. Definition of overactive bladder and epidemiology of urinary incontinence. Urology 1997;50(6A Suppl):4-14.

13. Rortveit G, Daltveit AK, Hannestad YS, Hunskaar S; Norwegian EPINCONT Study Urinary incontinence after vaginal delivery or caesarean section. N Engl J Med 2003;348:900-7.

14. Bump RC, McClish DK. Cigarette smoking and urinary incontinence in women. Am J Obstet Gynecol 1992;167:1213-8.

15. Dwyer PL, Lee ET, Hay DM. Obesity and urinary incontinence in women. Br J Obstet Gynaecol 1988;95:91-6.

16. Allen RE, Hosker GL, Smith AR, Warrell DW. Pelvic floor damage and childbirth: a neurophysiological study. Br J Obstet Gynaecol 1990;97:770-9.

17. Al-Mufti R, McCarthy A, Fisk NM. Obstetricians' personal choice and mode of delivery. Lancet 1996;347:544.

18. Dmochowski RR. Urinary incontinence: Proper assessment and available treatment options. J Womens Health (Larchmt) 2005;14:906-16.

19. Dywer PL, Rosamilia A. Evaluation and diagnosis of the overactive bladder. Clin Obstet Gynecol 2002;45:193-204.

20. Kohli N, Karram MM. Urodynamic evaluation for female urinary incontinence. Clin Obstet Gynecol 1998;41:672-90.

21. Hamann MF, Jünemann KP, Naumann CM. Urinary incontinence in men and women: Diagnostics and conservative therapy. Urologe A 2014;53:1073-86.

22. Khan IJ, Tariq SH. Urinary incontinence: behavioural modification therapy in older adult. Clin Geriatr Med 2004;20:499-509.

23. Viera AJ, Larkins-Pettigrew M. Practical use of the pessary Am Fam Physician 2000;61:2719-26.

24. Cox A, Herschorn S, Lee L. Surgical management of female SUI: is there a gold standard? Nat Rev Urol 2013;10:78-89.

25. Agur W, Riad M, Secco S, Litman H, Madhuvrata P, Novara G, et al. Surgical treatment of recurrent stress urinary incontinence in women: a systematic review and meta-analysis of randomised controlled trials. Eur Urol 2013;64:323-36.

26. Jeppson PC, Sung VW. Autologous graft for treatment of midurethral sling exposure without mesh excision. Obstet Gynecol 2013;121(2 Pt 2 Suppl 1):437-9.

27. Chughtai B, Barber MD, Mao J, Forde JC, Normand ST, Sedrakyan A. Association Between the Amount of Vaginal Mesh Used with Mesh Erosions and Repeated Surgery After Repairing Pelvic Organ Prolapse and Stress Urinary Incontinence. JAMA Surg 2017;152:257-63.

28. Davila GW. Nonsurgical outpatient therapies for the management of female stress urinary incontinence: long-term effectiveness and durability. Adv Urol 2011;2011:176498.

29. Lukban JC. Transurethral radiofrequency collagen denaturation for treatment of female stress urinary incontinence: a review of the literature and clinical recommendations. Obstet Gynecol Int 2012;2012:384234.

30. Elser DM, Mitchell GK, Miklos JR, Nickell KG, Cline K, Winkler H, et al. Nonsurgical transurethral radiofrequency collagen denaturation: results at three years after treatment. Adv Urol 2011;2011:872057.

31. Kang D, Han J, Neuberger MM, Moy ML, Wallace SA, Alonso-Coello P, et al. Transurethral radiofrequency collagen denaturation for the treatment of women with urinary incontinence. Cochrane Database Syst Rev 2015:CD010217.

32. Frederick RW, Leach GE. Stress Urinary Incontinence Secondary to Intrinsic Sphincteric Deficiency. Vaginal Surgery for incontinence and prolapse. In: Zimmern PE, Norton PA, Haab F, Chapple CCR, editors. Springer-Verlag London Limited; 2006:118-23.

33. Lucas MG, Bosch RJL, Burkhard FC, Cruz F, Madden TB, Nambiar AK, et al. EAU Guidelines on Surgical Treatment of Urinary Incontinence. Eur Urol 2012;62:1118 29.

34. Haab F, Zimmern PE, Leach GE. Urinary stress incontinence due to intrinsic sphincteric deficiency: experience with fat and collagen periurethal injections. J Urol 1997; 157:1283-6.

35. Kirchin V, Page T, Keegan PE, Atiemo KO, Cody JD, McClinton S, et al. Urethral injection therapy for urinary incontinence in women. Cochrane Database Syst Rev 2017;7:CD003881.
36. Mamut A, Carlson KV. Periurethral bulking agents for female stress urinary incontinence in Canada. Can Urol Assoc J 2017;11(6Supp12):S152-S154.

37. Sokol ER, Karram MM, Dmochowski RR. Efficacy and safety of polyacrylamide hydrogel for the treatment of female stress incontinence: A randomized, prospective, multicentre North American study. J Urol 2014;192:843-9.

38. Matsuoka PK, Locali RF, Pacetta AM, Baracat EC, Haddad JM. The efficacy and safety of urethral injection therapy for urinary incontinence in women: a systematic review. Clinics (Sao Paulo) 2016;71:94-100.

39. Lee JY, Paik SY, Yuk SH, Lee JH, Ghil SH, Lee SS. Long term effects of musclederived stem cells on leak point pressure and closing pressure in rats with transected pudendal nerves. Mol Cells 2004;18:309-13.

40. Xu Y, Song YF, Lin ZX. Transplantation of muscle-derived stem cells plus biodegradable fibrin glue restores the urethral sphincter in a pudendal nervetransected rat model. Braz J Med Biol Res 2010;43:1076-83.

41. Arjmand B, Safavi M, Heidari R, Aghayan H, T Bazargani S, Dehghani S, et al. Concomitant Transurethral and Transvaginal-Periurethral Injection of Autologous Adipose Derived Stem Cells for Treatment of Female Stress Urinary Incontinence: A Phase One Clinical Trial. Acta Med Iran 2017;55:368-74.

42. Lee CN, Jang JB, Kim JY, Koh C, Baek JY, Lee KJ. Human cord blood stem cell therapy for treatment of stress urinary incontinence. J Korean Med Sci 2010;25:813-6.

43. Peters KM, Dmochowski RR, Carr LK, Robert M, Kaufman MR, Sirls LT, et al Autologous Muscle Derived Cells for Treatment of Stress Urinary Incontinence in Women. J Urol 2014;192:469-76.

44. Kuismanen K, Sartoneva R, Haimi S, Mannerström B, Tomás E, Miettinen S, et al. Autologous adipose stem cells in treatment of female stress urinary incontinence: results of a pilot study. Stem Cells Transl Med 2014;3:936-41.

45. Aragón IM, Imbroda BH, Lara MF. Cell Therapy Clinical Trials for Stress Urinary Incontinence: Current Status and Perspectives Int J Med Sci 2018;15:195-204.

46. Falconer C, Larsson B. New and simplified vaginal approach for correction of urinary stress incontinence in women. Neurourol Urodyn 1995;14:365-70.

47. Killholma P, Haarala M, Polvi H, Mäkinen J, Chancellor MB. Sutureless endoscopic colposuspension with fibrin sealant. Tech Urol 1995;1:81-3.

48. Lapitan MC, Cody JD. Open retropubic colposuspension for urinary incontinence in women. Cochrane Database Syst Rev 2016;2:CD002912.

49. Vancaillie TG, Schuessler W. Laparoscopic bladder neck suspension. J Laparoendosc Surg 1991;1:169-73

50. Reid F, Smith AR. Laparoscopic versus open colposuspension: which one should we choose? Curr Opin Obstet Gynecol 2007;19:345-9.

51. Hong JH, Choo MS, Lee KS. Long-term results of laparoscopic Burch colposuspension for stress urinary incontinence in women. J Korean Med Sci 2009;24:1182-6.

52. Dean NM, Ellis G, Wilson PD, Herbison GP. Laparoscopic colposuspension for urinary incontinence in women. Cochrane Database Syst Rev 2006:CD002239.

53. Jenkins TR, Liu CY. Laparoscopic Burch colposuspension. Curr Opin Obstet Gynecol 2007; 19:314-8

54. Ankardal M, Milsom I, Stjerndahl JH, Engh ME. A three-armed randomized trial comparing open Burch colposuspension using sutures with laparoscopic colposuspension using sutures and laparoscopic colposuspension using mesh and staples in women with stress urinary incontinence. Acta Obstet Gynecol Scand 2005;84:773-9.

55. Singh I, Hemal AK. Role of robot-assisted pelvic surgery. Scientific World Journal 2009;9:479-89.

56. Orasanu B, Marotte J, Pasko B, Hijaz A, Daneshgari F. Robotic-assisted urethrolysis for urethral obstruction after retropubic bladder neck suspension-a case series report. J Endourol 2014;28:214-8.

57. Francis SL, Agrawal A, Azadi A, Ostergard DR, Deveneau NE. Robotic Burch colposuspension: a surgical case and instructional video. Int Urogynecol J 2015;26:147-8.

58. Bora GS, Gupta VG, Mavuduru RS, Devana SK, Singh SK, Mandal AK. Robotic Burch colposuspension-modified technique. J Robot Surg 2017;11:381-2.

59. Lowder JL, Ghetti C, Nikolajski C, Oliphant SS, Zyczynski HM. Body image perceptions in women with pelvic organ prolapse: a qualitative study. Am J Obstet Gynecol 2011;204:441.

60. Barber MD. Contemporary views on female pelvic anatomy. Cleve Clin J Med 2005;72(Suppl 4):3-11. 
61. Nygaard I, Barber MD, Burgio KL, Kenton K, Meikle S, Schaffer J, et al. Prevalence of symptomatic pelvic floor disorders in US women. JAMA 2008;300:1311-6.

62. Boyles SH, Weber AM, Meyn L. Procedures for pelvic organ prolapse in the United States, 1979-1997. Am J Obstet Gynecol 2003;188:108-15.

63. Jelovsek JE, Maher C, Barber MD. Pelvic organ prolapse. Lancet 2007;369:1027-38

64. Weber AM, Walters MD, Ballard LA, Booher DL, Piedmonte MR. Posterior vaginal prolapse and bowel function. Am J Obstet Gynecol 1998;179:1446-9.

65. Whitcomb EL, Rortveit G, Brown JS, Creasman JM, Thom DH, Van Den Eeden SK, Subak LL. Racial differences in pelvic organ prolapse. Obstet Gynecol 2009;114:1271-7.

66. Ignjatovic I, Stojkovic I, Basic D, Medojevic N, Potic M. Optimal primary minimally invasive treatment for patients with stress urinary incontinence and symptomatic pelvic organ prolapse: tension free slings with colporrhaphy, or Prolift with the tension free mid-urethral sling? Eur J Obstet Gynecol Reprod Biol 2010;150:97-101.

67. Swift S. Current opinion on the classification and definition of genital tract prolapse. Curr Opin Obstet Gynecol 2002;14:503-7.

68. Culligan PJ. Nonsurgical management of pelvic organ prolapse. Obstet Gynecol 2012; 119:852-60.

69. Panman CM, Wiegersma M, Kollen BJ, Burger H, Berger MY, Dekker JH. Predictors of unsuccessful pessary fitting in women with prolapse: a cross-sectional study in general practice. Int Urogynecol J 2017;28:307-13.

70. Deng M, Ding J, Ai F, Zhu L. Successful use of the Gellhorn pessary as a second-line pessary in women with advanced pelvic organ prolapse. Menopause 2017;24:1277-81.

71. Febbraro W, Beucher G, Von Theobald P, Hamel P, Barjot P, Heisert M, et al Feasibility of bilateral sacrospinous ligament vaginal suspension with a stapler.
Prospective studies with the 34 first cases. J Gynecol Obstet Biol Reprod (Paris) 1997;26:815-21

72. Tseng LH, Chen I, Chang SD, Lee CL. Modern role of sacrospinous ligament fixation for pelvic organ prolapse surgery a systemic review. Taiwan J Obstet Gynecol 2013;52:311-7.

73. Leone Roberti Maggiore U, Alessandri F, Remorgida V, Venturini PL, Ferrero S. Vaginal sacrospinous colpopexy using the Capio suture-capturing device versus traditional technique: feasibility and outcome. Arch Gynecol Obstet 2013;287:267-74.

74. Vaudano G, Gatti M. Correction of vaginal vault prolapse using Capio $^{\mathrm{TM}}$ suture capturing device: our experience. Minerva Ginecol 2015;67:103-11.

75. Khan A, Alperin M, Wu N, Clemens JQ, Dubina E, Pashos CL, et al. Comparative outcomes of open versus laparoscopic sacrocolpopexy among Medicare beneficiaries. Int Urogynecol J 2013;24:1883-91.

76. Freeman RM, Pantazis K, Thomson A, Frappell J, Bombieri L, Moran P, et al. A randomised controlled trial of abdominal versus laparoscopic sacrocolpopexy for the treatment of post-hysterectomy vaginal vault prolapse: LAS study. Int Urogynecol J 2013;24:377-84

77. Granese R, Candiani M, Perino A, Romano F, Cucinella G. Laparoscopic sacrocolpopexy in the treatment of vaginal vault prolapse: 8-years' experience. Eur J Obstet Gynecol Reprod Biol 2009;146:227-31.

78. Price N, Slack A, Jackson SR. Laparoscopic sacrocolpopexy: an observational study of functional and anatomical outcomes. Int Urogynecol J 2011;22:77-82.

79. Sarlos D, Kots L, Ryu G, Schaer G. Long-term follow-up of laparoscopic sacrocolpopexy. Int Urogynecol J 2014;25:1207-12.

80. Serati M, Bogani G, Sorice P, Braga A, Torella M, Salvatore S, et al. Robot-assisted Sacrocolpopexy for Pelvic Organ Prolapse: A Systematic Review and Meta-analysis of Comparative Studies. Eur Urol 2014;66:303-18. 